\title{
THE STRATEGIC MANAGEMENT OF GOVERNMENT AFFAIRS IN BRUSSELS
}

\section{Authors: David Coen University College London and Matia Vannoni University Bocconi}

\begin{abstract}
This article explores the strategic management of government affairs in companies active in the European Union (EU). The article relies on a unique large- $N$ dataset on the functioning and staffing of EU government affairs. The analysis shows that companies delegate government affairs functions to in-house managers with specific competences, who stay in office for long periods and who have an extensive knowledge of the core competences of the company, thanks to their educational background and work experience in the private sector. These findings suggest that how companies strategically manage and staff government affairs in Brussels rests on the distinct structure of business-government relations in the EU, which are based on the exchange of technical information and the establishment of credibility and long run trust arrangements.
\end{abstract}

Keywords: Business and Government, Corporate Political Activity (CPA), Government affairs, Lobbying. 
The number of firms politically active in the EU continues to grow and the political sophistication of their government affairs functions continues to evolve. Today, we see the development of specialized in-house government affairs departments, with an increasing number of professionals working there. The development of government affairs has been mainly studied in the public policy and management strands of literature as an organizational response to an increasing public involvement in the economic sphere. From a resource based perspective, scholars conceive of government affairs departments as an organizational resource indispensable to the company's political activity. The literature is also aware that different institutional settings affect business-government relations and how firms adapt their resources to the context.

Yet, the traditional focus on organizational resources overlooks the strategic management decisions taken by the company in the daily running of government affairs. This focus cannot explain, for instance, how companies delegate government affairs functions and to whom. In order to answer these questions, this article looks at how companies take strategic management decisions, in line with recent developments in the management literature (Lawton \& Rajwani, 2011; Lawton, Rajwani, et al., 2013). Drawing on a unique large- $N$ dataset on the functioning and staffing of government affairs departments in companies active in the EU, findings show that companies delegate government affairs functions to in-house managers with specific competences, who stay in place for long periods and possess a detailed knowledge of the core competences of the firm, thanks to their education and work background. This in turn depends on the specific business-government relations in place in the EU, which take the form of a trust based exchange of technical information.

This work makes two contributions. At theoretical level, we explain micro strategic management decisions by looking at macro business and government relations. In so doing, we 
bring together the scholarships of EU lobbying and management, which have traditionally, with few exceptions (Coen, 1997, 1998; Taminiau \& Wilts, 2006), developed apart. By looking at how macro business-government relations affect the micro management of government affairs, this article opens the way to a comparative approach to the study of government affairs. Significantly, while a great deal of attention has been paid to how macro institutional differences affect the allocation of organizational resources in the traditional corporate political activity (CPA) literature and to how specific policy environments affect micro strategic management decisions in more recent works, little attention has been paid to how macro institutional differences affect strategic management decisions. At the empirical level, although recent studies already look at strategic management decisions, such as the organization of government affairs (Lawton \& Rajwani, 2011; Lawton, Rajwani, et al., 2013), this work represents the first attempt to study this phenomenon from a large- $N$ perspective.

\section{The Rise of Professional Government Affairs}

The 1970s witnessed an increase in CPA at the federal level in the US, with several large American companies establishing a permanent presence in Washington. Previously, CPA was reactive and on an ad hoc basis (Yoffie \& Bergenstein, 1985) and its main functions were carried out through personal contacts between businessmen and politicians (Martin, 1994; Vogel, 1978). The few offices or divisions established in Washington were primarily in charge of sales and marketing (Yoffie \& Bergenstein, 1985). However, in the 1970s we saw a steady increase in legislative activity at federal level (Martin, 1994; Wilson, 1990) and a more active approach of Presidents in incentivising business presence in Washington (Martin, 1994), coupled with a more partisan organization of the Congress and the rise of competing interests (Martin, 1994, 1995; Vogel, 1987; Vogel, 1996a; Vogel, 1996b). This led, between 1960 to 1980, to a five-fold increase in the number 
of companies politically active in the capital, as well as in the size of the staff representing these companies (Yoffie \& Bergenstein, 1985). Hence, by 1990, most large American companies had established a permanent presence in the capital (Wilson, 1990).

The increasing importance of individual action was coupled with the decreasing relevance of collective forms of action, such as membership of national business associations (Wilson, 1990) and, more importantly, with the development of in-house government affairs departments (Marcus \& Kaufman, 1988; Martin, 1995; Post et al., 1983; Wilson, 1990; Yoffie, 1984). In the 1980s companies witnessed the creation of government affairs functions, separated from legal, public relations, finance and risk departments, and delegated to professional managers (Marx, 1986; Yoffie \& Bergenstein, 1985), in contrast to the activities of the 1960s (Cherington \& Gillen, 1962; Miller \& Johnson, 1970). As a result, the 1980s saw the emergence of a new professional way of organizing government affairs.

The EU witnessed a similar trend a few decades later. In the EU, the creation of a supranational authority with increasing responsibilities (Coen \& Richardson, 2009), along with an active campaign to encourage EU interest group activities by the European Commission and Parliament (Coen \& Grant, 2000; Coen et al., 2010) and the rising presence of consumer, environmental and civil society interest groups (Greenwood, 2011), pulled business to Brussels. Today, over 500 companies engage in direct EU lobbying; this figure has grown from approximately 50 firms in the 1980s, to 200 in 1990s, 300 in the 2000s and 400 in the 2010s (Coen, 2007, 2009; Greenwood, 2011; Wonka et al., 2010).

The increasing importance of an individual and permanent presence in Brussels furthered the development of professional government affairs functions (Bernhagen \& Mitchell, 2009; Coen, 1997, 1998, 2007; Kohler-Koch \& Quittkat, 1999; Kohler-Koch et al., 2013; Wilts \& Quittkat, 
2004). Since the mid-1980s, companies have allocated increasing resources to the establishment of government affairs departments in their headquarters, and these have often been complemented with offices in Brussels (Bernhagen \& Mitchell, 2009; Vannoni, 2015). Hence, by the mid-1990s, the majority of government affairs departments "had developed the strategic capacity to provide sophisticated peak level coordination over their subdivisions, cross-border holdings and subsidiaries" (Coen, 1998, p.80).

However, information on the actual size and organization of government affairs offices has been scarce. In the 1990s and 2000s most EU offices were relatively small, with roughly five individuals employed (Coen, 1998; Greenwood, 2011). Nevertheless, it should be noted that this represented a large investment for firms, with the cost of an office with two full time employees in Brussels starting from 300,000 Euros per year in 2000 (CIPI, 2006), compared to less than a tenth of this sum for an annual subscription to a European business association (Greenwood, 2011).

In our analysis, the dataset builds on the information gathered from the EU Transparency Register (CEC, 2014) and provides current information on the size of government affairs offices, with firms employing on average five officials in their government affairs offices. ${ }^{i}$ A closer look at the data reveals that firms on average employ three full-time equivalent (FTE) staff members in these offices. Hence, this study captures something so far overlooked, namely the use of part-time work in government affairs offices. Furthermore, the study also presents new insights on the annual costs firms incur in engaging in government affairs. Specifically, we note that firms report spending on average almost 600,000 Euros a year on in-house government affairs activities, such as the running of the EU offices, but also in other government affairs activities, such as the organization of events and the hiring of consultancies. 
The interviews conducted for this study confirm the increasing importance and professionalization of EU government affairs in companies. An experienced EU government affairs manager admitted that "at the beginning it was more a self-invented job". ii Moreover, several interviewees observed that nowadays the role of government affairs is more appreciated within companies, ${ }^{\text {iii }}$ especially in highly regulated sectors, where government affairs are seen as an insurance against political risks, but also as an investment in terms of political opportunities. ${ }^{\text {iv }}$

The above section discussed how the study of government affairs evolved, namely as an organizational response to an increasing public involvement in the economic sphere, and that both the US and the EU witnessed the rise of professional government affairs. In the US, we observed during the 1980s the increasing legislative activity at federal level and concurrent increase in business and countervailing interest groups. Similarly, in the 1990s in the EU we saw how the supranational institutions, and the increasing number of single market directives, pulled both economic and societal interest groups in to Brussels in large numbers. These phenomena led to the rise of professional, but as we will note below, different government affairs functions.

\section{A Micro-level Approach to Government Affairs}

The study of government affairs as an organizational response to the involvement of the state in the economy does not fully explain how companies delegate government affairs functions and to whom. To do so, we propose a micro-level approach to CPA, which helps explain how companies take strategic management decisions in government affairs.

Since the 1980s, management scholars have investigated what brings companies to the political arena, focusing on profits and the reduction of uncertainty and transaction costs (Getz, 2001). However, in the 1990s, attention shifted to the study of different types of CPA (Getz, 1997; 
Hillman \& Hitt, 1999; Lord, 2000; Schuler et al., 2002; Shaffer, 1995) and the determinants of this choice, such as firm, industry, policy and national level factors (Keim \& Baysinger, 1988; Shaffer, 1995). One central avenue of study within CPA has been the development of government affairs functions (Yoffie, 1984; Yoffie, 1985; Yoffie \& Bergenstein, 1985) and recent work has sort to investigate the overall organizational structure of these offices (Hillman et al., 2004; Lux et al., 2011; Martin, 1995) and the location of business-government relations within the corporate strategy of the firm (Baron, 1995; Hillman et al., 2009).

One of the mainstream approaches to the study of CPA has been the resource dependence theory. By building on sociological studies (Getz, 2001), the resource dependence theory asserts that companies engage in a resource exchange with the public authority for access and influence (Hillman et al., 2004; Lawton, McGuire, et al., 2013; McWilliams et al., 2002; Meznar \& Nigh, 1995). As such, recent CPA studies have recognized that to best understand political exchange we must understand the organizational structure, staffing and capacity of firms' government offices, and, on the demand side, the differing institutional informational needs. Today professional government affairs departments are seen as paramount to a successful political strategy for a firm.

Significantly, however, the main proponents of the management approach have noted that the study of CPA, and by extension the study of government affairs, has thus far lagged behind in developing a micro-level approach (Hillman et al., 2004; Shaffer \& Hillman, 2000): "we believe that the CPA perspective needs to be further explored, from within individual government affairs functions" (p.99) (Lawton, McGuire, et al., 2013). In the last 20 years, as noted by Foss (2011), the study of management shifted its focus to the firm level, and in recent years, to its processes and procedures, laying down the micro-foundations for the resource based theory (Barreto, 2010). This shift elicits two implications: the introduction of the concept of capabilities, as opposed to 
resources, and a revamped attention on strategic management (Teece, 2007). First, by building on evolutionary economics (Gavetti, 2005), the literature started to look at routines and processes, in terms of individual behaviours rather than organizational resources (Teece, 2007; Wang \& Barney, 2006). Capabilities are defined as the organization's capacity to more effectively use its resources in a particular environment (Oliver \& Holzinger, 2008). As a result, greater attention was paid to knowledge creation and to how the individual lies at its basis, for instance (Corredoira \& Rosenkopf, 2010; Felin et al., 2012; Felin \& Hesterly, 2007). Second, this extension of the resource based theory has assumed a strong strategic management connotation (Teece \& Pisano, 1994). In fact, while the company cannot easily adapt its organizational resources to gain competitive advantage, it can adapt its capabilities by, for instance, delegating certain functions, creating certain positions within its structure and hiring individuals with certain skills and experience (Campbell et al., 2012; Wang \& Barney, 2006). As such, the focus has been on human capital investments (Wang \& Barney, 2006). For instance, Mäkelä et al. (2012) investigate the individual level determinants of capabilities in Human Resources (HR) in multinational corporations. Among other things, they focus on HR managers' work experience, central in determining the level of strategic HR capabilities in the company (Zollo \& Winter, 2002).

Some recent studies look at CPA from a micro-level perspective (Lawton \& Rajwani, 2011; Lawton, Rajwani, et al., 2013; Oliver \& Holzinger, 2008). The main focus is on the choice of the most effective strategies to influence public policy, given the specific policy environment in which the company acts. Different strategies, in turn, are supported by different internal and external capabilities (Oliver \& Holzinger, 2008). Some of these studies focus on how, given the array of options of capabilities at hand, senior management makes a choice in specific policy contexts, looking also at the organization of government affairs (Lawton, Rajwani, et al., 2013). 
This work advances this micro-level approach, by focusing on how macro business and government relations affect the allocation of capabilities at micro level. More specifically, we look at how the specific EU business and government relations affect the strategic decisions companies take in terms of the functioning and staffing of government affairs departments. The delegation of government affairs functions to a specific role and the hiring of managers with specific experience and skills are conceived of as capabilities. In turn these capabilities allow the company to better deploy its organizational resources to gain comparative advantage in the political arena. A microlevel approach allows us to explain the differences in how companies manage government affairs. In fact, organizational resources, such as the development of professional government affairs functions, are arguably common to all political systems. Conversely, capabilities can be (and, indeed, are) easily adapted to the business-government relations in place in a particular system. Our theoretical contribution to the management literature is linking the macro business and government environment where companies are active with their micro strategic management choices.

By building on the US experience, the following section formulates hypotheses regarding the strategic management of EU government affairs. The US literature has already looked at government affairs functions in detail, and has suggested a distinct set of business-government relations. In the following section, we seek to make sense of how these distinct US businessgovernment relations affect the strategic management of government affairs in Washington, and to understand what can be generalized. In this vein, we put forward hypotheses on how the distinct form of business-government relations in the EU affect the strategic management of government affairs in Brussels. 


\section{Government Affairs in the US}

The literature suggests that distinct US business-government relations are in place in Washington: companies exchange votes and funds with political actors in exchange for rent. Furthermore, the literature also looks at how government affairs functions are managed: companies make large use of external consultancies and hire managers with educational backgrounds in law or public relations, and work experience in the public sector, to deal with government affairs. Moreover, these managers tend to be appointed for short periods of time. By applying a micro-level approach to CPA, we suggest that these two aspects are correlated. Different business-government relations require different capabilities in government affairs, such as knowledge of the workings of the political and bureaucratic machines, and personal contacts.

The American literature suggests that CPA in the US is rather adversarial (Mahoney, 2007; Vogel, 1978), being conceived as an economic transaction where firms provide the government with funds and votes in exchange for (regulatory) rent (Getz, 1997; Hillman et al., 2004; Keim, 2001; Keim \& Baysinger, 1988; Lawton, McGuire, et al., 2013; Lord, 2000; Masters \& Keim, 1985). Exchange theories in the traditional US political science and political economy literatures are in line with management studies, arguing that with campaign contributions lobbyists buy support from key politicians (Austen-Smith \& Wright, 1992, 1996; Stigler, 1971) or time from already sympathetic legislators (Denzau \& Munger, 1986). Furthermore, it has been argued that in constituency based electoral systems, like the American one, business can exert influence on legislators due to its importance for the local economy, which in turn translates into a capacity to mobilize votes (Grossman \& Helpman, 1996; Lindblom, 1977). Lastly, key differences are present between the public and the private sector in the US, in terms of employment conditions, which have significant effects on the relationship between business and government. Congressional staff 
are subject to work conditions which are less advantageous than those in the private sector, in terms of remuneration, benefits and job security (Cain \& Drutman, 2014), and Congressional staff have historically been subject to high levels of turnover (Che, 1995).

As a result, US companies hire professional government affairs managers with unique knowledge of the political and bureaucratic machine and personal contacts in government. In the 1950s and 1960s, representatives used to come from inside the company, whereas in the 1980s companies started to hire lawyers and public relations professionals with experience in government (Yoffie \& Bergenstein, 1985). First-hand experience in government and personal contacts there have been demonstrated to be key capabilities in influencing and gaining access to government (Bertrand et al., 2011; LaPira \& Thomas, 2014). In fact, in Washington lobbyists tend to follow their contacts in the public sector when they are re-assigned to a different portfolio (Bertrand et al., 2011). The result is the well-documented phenomenon of the revolving door, with government affairs managers usually coming into the private sector from public service and political parties (Blanes i Vidal et al., 2012; Cain \& Drutman, 2014; Che, 1995; Cohen, 1986; Gormley, 1979; LaPira \& Thomas, 2014; Lazarus et al., 2016; Lazarus \& McKay, 2012). Significantly, the high turnover in Congressional staff results in high turnover among government affairs managers and in-house lobbyists (LaPira \& Thomas, 2014). For the same reasons, in the US companies make large use of external consultancies (LaPira \& Thomas, 2014).

In sum, distinct business-government relations require distinct capabilities in order for the company to maintain competitive advantage in the political arena. In the US, business-government relations are based on an exchange of votes or funds for rent. As such, companies hire government affairs managers with law/public relations educational backgrounds and work experience in the public sector, who have knowledge of how the political and bureaucratic machines work and who 
have personal contacts there. Furthermore, these government affairs managers do not stay for long in that position and are often supported by external consultancies.

\section{Government Affairs in the EU}

By building on the US experience, this section looks at the business-government relations in place in the EU and formulates hypotheses on how these distinct relations affect the strategic management of government affairs in Brussels (i.e. the allocation of capabilities). In contrast to the US, business-government relations in the EU are based on the exchange of a specific currency: technical information. EU legislators are not dependent on business in terms of money and votes, since most of them are not directly elected and their legitimacy depends on the quality of regulation (Majone, 1997; Moravcsik, 2002). Even where direct elections are in place, such as for Members of the European Parliament (MEPs), it has been demonstrated that EU citizens rarely vote on the basis of what MEPs do at the EU level (Hix \& Marsh, 2007; Hobolt et al., 2009). Furthermore, funding to political parties in the European Parliament (EP) is mainly public and the EU has historically funded civil society organizations rather than the other way round (Mahoney, 2004; Mahoney \& Beckstrand, 2011). What EU legislators need is high-quality technical information on the specific issues concerning a sector, which business is well placed to provide (Bouwen, 2002, 2004). The literature suggests that this exchange of information does not take place as an economic transaction, but it is based on a network of trust and credibility (Broscheid \& Coen, 2003; Coen, 2007, 2009). EU institutions, especially the Commission, rely on the information exchanged with a relatively small inner circle of societal actors, among which business plays a central role (Bouwen, 2002, 2004). Access to this inner circle is based on trust and credibility. Societal actors are assessed on the basis of the information they send, and if they break the trust by sending biased information, they are excluded from this network (Broscheid \& Coen, 2003, 2007). This network 
of trust and credibility is reinforced by the fact that EU officials enjoy high benefits, long run permanent contracts and are subject to little turnover. As such, business must learn to work with the same government officials over time and build political reputation.

Micro strategic management decisions refer to decisions concerning the allocation of political capabilities. Capabilities refer to processes and procedures, embedded in the organization of the firm, which allow the company to exploit its organizational resources, such as professional government affairs staff, in order to be more competitive in a specific macro business and government environment. In the EU, companies allocate capabilities in order to establish more effective long-term and trust-based relationships with their public counterpart and provide the latter with reliable technical information. We identify three capabilities: the delegation of government affairs, the type of appointment of government affairs managers and their skills. In the EU, those companies which delegate government affairs functions to in-house managers with specific competences, who stay in office for long periods and who are able to provide EU institutions with technical knowledge of the industry, thanks to their educational and professional background, have a comparative advantage in the political arena. Table 1 summarizes the discussion.

The first hypothesis is that companies active in the EU delegate government affairs to inhouse managers with specific competences. In these companies, government affairs functions are different from public relations or communications functions. Interviews show that the role of government affairs managers within companies is functionally differentiated from their colleagues in the legal, public relations, finance and risk departments and technical experts. This role is to coordinate between different national offices and make sure the firm speaks with a unified voice. As one interviewee noted, "they act as glue" in holding together a single perspective across 
different departments and along the policy process. ${ }^{\mathrm{v}}$ The role of government affairs managers is to act as a bridge between the public authorities, in this case the EU, and the company. In so doing, they act as gate-keepers, controlling information from the inside out, but also from the outside in: they "lobby internally and externally". ${ }^{\text {vi }}$ In fact, they have to make sure that technical information is made understandable for decision-makers. As an interviewee observed, government affairs managers have to act as "kind of translators". vii Yet, it should not be forgotten that information flows are not just out of the company, as government affairs managers are also in charge of managing information requests from the public authorities into the company. As stated by one of the interviewees: "I have become a sort of European agent spreading the European rules and approach inside my company". viii

Relatedly, it is expected that companies make little use of external consultancies. Indeed, external consultancies cannot help build long-term relations with decision-makers, based on mutual trust. This is suggested in several interviews, where it was noted that external consultancies are not regularly used. ${ }^{i x}$ When used, it is mainly to monitor broad horizontal political issues, which affect the business environment as a whole, and not specifically to make representation for the company/sector. The reason is that the use of external consultancies fails to build a company's reputation, or direct good will in the EU public policy realm. ${ }^{\mathrm{x}}$ In conclusion, companies politically active in the EU tend to delegate government affairs to in-house managers with specific functions and do not make large use of external consultancies. The reason is that in-house managers are functional in their relationships, seeking to maintain long-term relations with the public counterpart and establish trust both within the firm and outside it with EU institutions. 
H1: Companies politically active in the EU tend to delegate government affairs to inhouse managers with specific functions and do not make large use of external consultancies

The second hypothesis is that companies' representatives need to provide some sort of continuity with respect to their counterparts in the EU institutions, who stay in the role for long periods. An EU government affairs manager interviewed for this study emphasised that the low turnover among EU officials impacts how they recruited individuals in government affairs offices. ${ }^{\text {xi }}$ As such, government affairs managers tend to be appointed for long periods.

$\mathrm{H} 2$ : Companies politically active in the EU tend to delegate government affairs to managers appointed for long periods

The last hypothesis concerns the skills managers need to possess. EU government affairs managers need to know how their industry works. These skills are usually acquired with work experience in the private sector. An education background in social science provides managers with highly transferrable skills, such as project management, ${ }^{\text {xii }}$ which in turn can be complemented by the specific knowledge of an industry obtained in the field. Interviewees suggest that an education in social sciences might be the best starting point to become an EU government affairs manager. As put by one interview, "a degree in political science as a starter is probably one of the most useful things". xiii Experience in the company's core competences is then acquired in the field, through work experience. Indeed, EU government affairs managers need to be experts in the core competences of the company, but they also need to work in a political environment. This balance was emphasised by several interviewees. One interviewee asserted that people working in his department need to understand at least 60 per cent of the technical debates going on within the 
firm and that if they understand less or more this means that they are working in the wrong department - this is what he calls the "60 per cent rule" xiv

H3: Companies politically active in the EU tend to delegate government affairs to managers with an educational background in social science and work experience in the private sector

Table 1 below summarizes the main characteristics of the business and government relations in the EU and the US and how they affect the allocation of capabilities in government affairs. In the US business and government relations are mainly short term economic transactions based on the exchange of votes and funds. This arrangement requires a specific management of government affairs, based on external consultancies, high turnover within government affairs department and the focus on personal contacts. Conversely, in the EU business and government relations are longterm trust based exchanges of information. This specific environment in turn requires the use of in-house managers who stay in place for long time and who know the industry.

Insert Table 1 about here

\section{Research Design}

This article opens up the black box of government affairs departments, by exploring who is employed as government affairs managers in companies politically active in the EU and what their functions are. This study relies on a unique dataset containing information on 325 government affairs managers, identified from public and private directories, namely the 2014 DOD's European 
Government affairs Directory (DODs, 2014) and the EU Transparency Register (CEC, 2014). The Transparency Register (CEC, 2014) is close in spirit to the traditional lobbyists' register, as can be found in several countries. Among other things, for each company registered it contains information on who is in charge of EU government affairs, under the entry 'Person in Charge of EU Relations.' The same information is available from the 2014 DOD's European Public Affairs Directory, which provides a list of all the individuals in charge of in-house EU government affairs.

These managers are employed in companies politically active in the EU from 32 countries, 13 sectors and ranging from a size of few employees to hundreds of thousands. Information on the companies is gathered from AMADEUS (BureauVanDijk, 2014). Information on managers' roles and their professional and educational background, namely where they had worked immediately before moving to the current company and where/what they studied at university, is drawn from the directories mentioned above and professional social networks, such as LinkedIn. This study also contains unique data on the political activities of the firm, presenting the size of the government affairs office, the lobbying expenses and the consultancies employed. This is drawn from the EU Transparency Register (CEC, 2014). As such, this work is the first large- $N$ study of its kind.

Finally, in-depth information on how government affairs departments work, their role within the firm, and who works there is gathered through elite interviews with 10 senior government affairs managers employed in a sample of companies from the dataset used in this work. A series of faceto-face and telephone interviews were conducted in February and March 2016. The aim of these interviews was to validate the findings of the main analysis (Hochschild, 2009; Tansey, 2007). The sample used was non-probabilistic, based on snowballing (Davies, 2001), in order to give more 
relevance to key actors (Tansey, 2007). Finally, interviews were semi-structured and lasted on average one hour (Harvey, 2011).

\section{Findings}

This section tests the hypotheses formulated above (see also Table 1). Our first hypothesis suggests that companies politically active in the EU tend to delegate government affairs to in-house managers with specific functions and do not make large use of external consultancies. We test this hypothesis first by looking at the competences of the managers in charge of EU public policy and then by looking at whether companies use private companies to further their interests.

The findings show that almost half of the companies employ middle level and functionally specific roles, such as Director of (European) Government Affairs. In these companies, government affairs functions are differentiated from others, such as public relations, and are delegated to specific managers. Findings show also that almost half of the managers in the study have competences geographically specific to the EU or Europe.

Nonetheless, Figure 1 and Figure 2 show that some variation is present in the degree of differentiation and decentralization of government affairs functions. In some companies government affairs are dealt with by more senior managers, such as (deputy managing, executive or senior) director and (senior) vice president: these roles represent important management positions in the company, just below the president or the managing director. This variation in the delegation of government affairs can be explained by country and industry factors. Figure 1 shows the percentage of senior and junior positions in charge of EU government affairs across country (the top-right quadrant considers whether the country is in the EU or not and the bottom-left quadrant groups countries according to families), firm size and industry. The findings suggest that 
a statistically significant association is present between country and industry variables and the delegation of government affairs functions to junior or senior managers (with $\mathrm{p}<0.001$ ). Figure 1 shows that companies in highly regulated fields, such as transportation and telecommunications, employ more junior and functionally specialized managers in their government affairs departments. This is not surprising, as in these industries the need for corporate political activity is stronger than in others and as such companies employ managers with specific government affairs functions to deal with different regulation levels. In sectors where regulation is less prominent, companies delegate government affairs functions to senior managers with broad competences.

Moreover, the findings suggest that although no difference is present between EU and nonEU countries, there is a statistically significant relationship between the country of origin of the company and the delegation of government affairs functions to junior or senior managers (with $\mathrm{p}<0.001)$. Anglo-Saxon managers are more senior, while Continental companies show equal levels of senior and junior positions. Instead, Mediterranean countries show higher levels of junior managers. The tendency to delegate government affairs functions to key individuals might reflect the high importance of government affairs and lobbying in the Anglo-Saxon business culture. Conversely, in Continental and Mediterranean business cultures government affairs and lobbying have historically played a less central role and hence these functions are delegated to individuals in lower ranks.

Insert Figure 1 about here 
Some variation in terms of country and firm size is also present in the level of decentralization of government affairs. Figure 2 shows the percentage of managers with specific geographic competences (on the EU/Europe) across country, size and industry. First, where the headquarters of the firm are based affects how the firm organizes government affairs. The country of origin is statistically related to the geographic focus of government affairs managers (with $\mathrm{p}<0.05$ for the variable EU and with $\mathrm{p}<0.001$ for the variable Country Group). Firms outside the EU tend to appoint managers to deal specifically with the EU institutions, as shown in the top right quadrant of Figure 2. Furthermore, the distance from Brussels appears to matter, for instance Belgian and Dutch firms do not differentiate government affairs functions geographically, whereas Spanish firms do - as shown in the bottom left quadrant of Figure 2. These findings may be due to the need to establish a permanent presence in Brussels: companies in the EU and especially companies close to Brussels already have the organizational resources to deal with EU institutions effectively, whereas companies with headquarters outside the EU, or simply far from Brussels, need to create specific roles and functions on purpose. Second, the top left quadrant of Figure 2 demonstrates that the size of the company matters. Firm size is statistically related to the geographic focus of government affairs managers (with $\mathrm{p}<0.001$ ). Small firms tend not to have developed corporate governance structures with distinct departments in charge of government affairs. In fact, in small firms government affairs are less developed and they appoint a single individual to deal with different regulatory arenas.

Insert Figure 2 about here 
Most companies politically active in the EU delegate government affairs functions to roles which are separated from public relations and communications roles and which deal specifically with the EU, or the European region at least. Although some important variation across firm, industry and country level is present, this finding provides support for the first hypothesis set out above.

The first hypothesis also concerns the use of external consultancies. Indeed, it is expected that companies politically active in the EU delegate government affairs functions to in-house managers with specific functions, which is demonstrated above, but also that they do not make extensive use of external consultancies.

The findings suggest that the use of external consultancies is limited, and to a certain extent complementary to, rather than a substitute for, in-house government affairs. Slightly more than half of the firms in the dataset regularly hire public and government affairs consultancies: a figure which pales in comparison with the situation in the US, where the hiring of private lobbyists and external consultants is common practice (LaPira \& Thomas, 2014). Moreover, the findings show that the use of external consultants and the size of the public in-house affairs office are correlated (with $\mathrm{p}<0.001$ ). Again, this supports our expectation that in the EU mutual trust in businessgovernment relations is created through long-term interactions between public officials and company representatives. The use of external consultancies is not a capability which can create comparative advantage in this scenario and rather, can be detrimental. It is reasonable to assume that external consultancies are used only to complement corporate political activity through inhouse government affairs. 
The second hypothesis concerns the type of appointment of the government affairs managers. As government affairs functions take place in an environment where companies need to establish long-term relations based on trust, with public officials in place for long periods, it is expected that companies delegate government affairs functions to managers who stay in place for long periods as well.

The managers in the sample show high levels of longevity, having on average spent six years in their positions, and some as many as ten years. No statistically significant variation is found between longevity and firm, industry and country level factors. This supports our expectation that since in the EU business-government relations are based on mutual trust, which in turn require time to create, government affairs managers stay in their roles for long periods, and are able to create social capital in the EU institutions and within the company itself. This is reinforced by the fact that EU officials have long-term contracts and stay in charge of a single portfolio for long periods, as noted above, and hence companies need to mirror these dynamics.

The last hypothesis set out above is that government affairs in the EU rely on specific skills, namely in-depth knowledge of the core competences of the firm. In order to regulate different policy areas, EU institutions need timely technical information from companies. This is key in EU business-government relations. Accordingly, managers need to have specific scientific knowledge, which can come from education or work experience. As already emphasised in micro-capability approaches applied to other fields (Zollo \& Winter, 2002), the work experience of key employees is crucial to determine the level of strategic capabilities

The findings show that more than a third of the managers in the study are educated (in their first degree) in social sciences. Languages, law and humanities feature less prominently. 
Moreover, very few managers have first degrees in business and management, or professional education. The situation is rather different for the second degree though, where managers holding a management and business degree (i.e. executive education) are prominent. An apparent pattern seems to be present in this case, with EU managers as highly qualified individuals, with a traditional secondary education in social sciences, followed by an executive qualification.

Some variation is present across countries, industries and firm size, as shown in Figure 3. This variation might be explained by different national business cultures, and by the fact that some industries deal with more technical products or services than others (as suggested above), and hence managers in these industries need a more technical education. Moreover, it is reasonable to assume that in small companies senior managers with general educations are in charge of different functions, including government affairs.

Figure 4 shows the professional background of EU government affairs managers across firm size, country and industry. The findings show that the professional background of government affairs managers is mainly in the private sector, with few of them having experience also in public affairs companies and law firms. No statistically significant variation is present across firm size and countries. Mild variation is present only across industries, which might be explained by the fact that some industries are more technical than others and as such, in those industries technical knowledge is particularly important. Finally, it should be noted that very few EU government affairs managers have work experience in the public sector, which contrasts starkly with the US. As seen above, in the US business-government relations the political currency is the knowledge of the political machine and personal contacts, while in the EU these factors matter less. As such, little personnel exchange between the public and the private sector is present. This is in line with recent work which suggests that Brussels is characterised by a system closer in spirit to sliding 
doors than revolving doors, where there is a neat separation between private and public careers (Coen \& Vannoni, 2016).

Findings about the educational and professional background of EU government affairs managers support the last hypothesis set out above. In the EU the political currency is technical information and in order to provide EU institutions with this currency, companies adopt specific capabilities, such as hiring individuals with technical knowledge of the core competences of the firm. This technical knowledge is usually acquired in the field, namely with work experience in the private sector.

Insert Figure 3 about here

Insert Figure 4 about here

This final part provides further confirmation for the first hypothesis above, by exploiting variation in the level of political activity across companies. Indeed, it is reasonable to expect that the level political activity in the EU is associated with the extent to which companies delegate government affairs functions to in-house managers with specific competences. Table 2 and Table 3 show the results of multivariate logistic regression models with the outcome variable specified as whether the government affairs manager in the firm has competences geographically specific to 
the EU or Europe, and with lobbying costs and the size of the government office as indicators for the level of political activity in the EU, respectively. The findings suggest that the more a company invests in corporate political activity in the EU (by allocating more resources, in terms of money and people), the more it will delegate to decentralized in-house government affairs managers. These findings are robust also when controlling for the size of the company, as well as the country and industry of the company.

The multivariate regression analysis provides further confirmation for the first hypothesis formulated above, adding validity to the results in this article. Results for control variables are also consistent with the bivariate analysis above. Indeed, the level of decentralization of government affairs is associated with the country of origin of the firm, as suggested above. Table 1 and Table 2 show that whether a company comes from outside the EU, or even far from Brussels, such as Scandinavian countries, this company is more likely to have a government affairs manager with specific competences for Europe or the EU. These results are robust also when controlling for other factors, most notably firm size.

Insert Table 2 about here

Insert Table 3 about here 
Overall, the findings support the hypotheses formulated above. Companies politically active in the EU delegate government affairs functions to in-house managers with specific competences, who stay in place for long periods and who have technical knowledge of the core competences of the firm, thanks to their education and professional background. This is arguably due to the distinct structure of business-government relations in the EU, where companies exchange technical information with EU institutions and where mutual trust plays a crucial role. Companies strategically manage government affairs by delegating specific functions and appointing individuals with specific skills to carry out these functions, in order to obtain a comparative advantage in the political arena.

\section{Conclusion}

By looking at the strategic management of government affairs, this article applies a micro-level approach to the study of CPA in the EU. This approach moves the attention from organizational resources, such as the development of professional government affairs, to the allocation of capabilities at the micro-level, such as the allocation of human capital with determined skills and functions in charge of government affairs. Our main theoretical contribution is looking at how the strategic management of government affairs at the micro level varies according to the macro business-government relationships, which in turn provides the opportunity for more systematic comparative analysis.

In the US it has been demonstrated that corporate political activity can be seen as an economic transaction between business and government. The most valuable political resource is unique access to key decision-makers. As such, we observe a great deal of traffic through revolving doors as companies seek to hire managers with work experience in the public sector. The lobbying 
industry is therefore characterized by former politicians and bureaucrats running government affairs offices and is subject to high turnover.

This article, drawing on an original large- $N$ dataset, shows that companies politically active in the EU delegate government affairs functions to in-house managers with specific competences, who are appointed for long periods and have in-depth knowledge of the sector. The reason lies in the distinct EU institutional arrangements and the business-government relations. In Brussels, where the credibility of the policy relies on the quality of the information, the most valuable currency is technical information and knowledge of the market, and as such companies hire managers with experience of the sector and credibility within the company acquired over time. In sum, for the business-government relations to work in Brussels there must be trust and credibility between EU officials and company representatives based on experience and understanding of the regulatory issues. 


\section{Acknowledgements}

We wish to thank the participants of the European Interest Group Mobilization panel of the 2017

EUSA conference for useful comments, as well as three anonymous reviewers and the editors of Business and Society.

\section{Funding}

This work was supported by the British Academy [British Academy/Leverhulme Small Research Grant number 522590]. 


\section{References}

Austen-Smith, D., \& Wright, J. R. (1992). Competitive lobbying for a legislator's vote. Social Choice and Welfare, 9(3), 229-257.

Austen-Smith, D., \& Wright, J. R. (1996). Theory and evidence for counteractive lobbying. American Journal of Political Science, 40(2), 543-564.

Baron, D. P. (1995). Integrated strategy: Market and nonmarket components. California management review, 37(2), 47-65.

Barreto, I. (2010). Dynamic Capabilities: A Review of Past Research and an Agenda for the Future. Journal of Management, 36(1), 256-280.

Bernhagen, P., \& Mitchell, N. J. (2009). The Determinants of Direct Corporate Lobbying in the European Union. European Union Politics, 10(2), 155-176.

Bertrand, M., Bombardini, M., \& Trebbi, F. (2011). Is it whom you know or what you know? An empirical assessment of the lobbying process. The American Economic Review, 104(12), 3885-3920.

Blanes i Vidal, J., Draca, M., \& Fons-Rosen, C. (2012). Revolving door lobbyists. The American Economic Review, 102(7), 3731-3748.

Bouwen, P. (2002). Corporate lobbying in the European Union: the logic of access. Journal of European Public Policy, 9(3), 365-390.

Bouwen, P. (2004). Exchanging access goods for access: A comparative study of business lobbying in the European Union institutions. European Journal of Political Research, 43(3), 337-369.

Broscheid, A., \& Coen, D. (2003). Insider and outsider lobbying of the European Commission: an informational model of forum politics. European Union Politics, 4(2), 165-189.

Broscheid, A., \& Coen, D. (2007). Lobbying activity and fora creation in the EU: empirically exploring the nature of the policy good. Journal of European Public Policy, 14(3), 346-365.

BureauVanDijk. (2014). AMADEUS.Retrieved January 2014 from https://amadeus.bvdinfo.com/version2016419/home.serv?product=amadeusneo

Cain, B., \& Drutman, L. (2014). Congressional staff and the revolving door: the impact of regulatory change. Election Law Journal: Rules, Politics, and Policy, 13(1), 27-44.

Campbell, B. A., Coff, R., \& Kryscynski, D. (2012). Rethinking sustained competitive advantage from human capital. Academy of Management Review, 37(3), 376-395.

CEC. (2014). Transparency Register Retrieved June 2014 from http://ec.europa.eu/transparencyregister/info/homePage.do

Che, Y.-K. (1995). Revolving doors and the optimal tolerance for agency collusion. The Rand Journal of Economics, 26(3), 378-397.

Cherington, P. W., \& Gillen, R. L. (1962). The business representative in Washington. Washington, DC: The Brookings Institution.

CIPI. (2006). Le lobby d'Italia a Bruxelles. Brussels, Belgium: All Printing Services-CIPI.

Coen, D. (1997). The evolution of the large firm as a political actor in the European Union. Journal of European Public Policy, 4(1), 91-108.

Coen, D. (1998). The European business interest and the nation state: large-firm lobbying in the European Union and member states. Journal of Public Policy, 18(01), 75-100.

Coen, D. (2007). Empirical and theoretical studies in EU lobbying. Journal of European Public Policy, 14(3), 333-345.

Coen, D. (2009). Business lobbying in the European Union. In D. Coen \& J. Richardson (Eds.), Lobbying the European Union: institutions, actors and issues (pp. 145-168). Oxford, UK: Oxford University Press.

Coen, D., \& Grant, W. (2000). Corporate political strategy and global policy: a case study of the Transatlantic Business Dialogue. European Business Journal 13(1), 37 - 44. 
Coen, D., Grant, W., \& Wilson, G. (2010). The Oxford handbook of business and government. Oxford, UK: Oxford University Press.

Coen, D., \& Richardson, J. (2009). Lobbying the European Union: institutions, actors, and issues. Oxford, UK: Oxford University Press.

Coen, D., \& Vannoni, M. (2016). Sliding doors in Brussels: a career path analysis of EU affairs managers. European Journal of Political Research, 55(4), 811-826.

Cohen, J. E. (1986). The dynamics of the revolving door on the FCC. American Journal of Political Science, 30(4), 689-708.

Corredoira, R. A., \& Rosenkopf, L. (2010). Should auld acquaintance be forgot? The reverse transfer of knowledge through mobility ties. Strategic Management Journal, 31(2), 159-181.

Davies, P. H. J. (2001). Spies as informants: triangulation and the interpretation of elite interview data in the study of the intelligence and security services. Politics, 21(1), 73-80.

Denzau, A. T., \& Munger, M. C. (1986). Legislators and interest groups: how unorganized interests get represented. The American Political Science Review, 80(1), 89-106.

DODs. (2014). European Union and public affairs directory: 2014 : the essential guide to the institutions and public affairs community in Brussels. London, UK: Dod's Parliamentary Communications.

Felin, T., Foss, N. J., Heimeriks, K. H., \& Madsen, T. L. (2012). Microfoundations of routines and capabilities: individuals, processes, and structure. Journal of Management Studies, 49(8), 1351-1374.

Felin, T., \& Hesterly, W. S. (2007). The knowledge-based view, nested heterogeneity, and new value creation: Philosophical considerations on the locus of knowledge. Academy of Management Review, 32(1), 195-218.

Foss, N. J. (2011). Invited editorial: why micro-foundations for resource-based theory are needed and what they may look like. Journal of Management, 37(5), 1413-1428.

Gavetti, G. (2005). Cognition and hierarchy: rethinking the microfoundations of capabilities' development. Organization Science, 16(6), 599-617.

Getz, K. A. (1997). Research in corporate political action integration and assessment. Business \& Society, 36(1), 32-72.

Getz, K. A. (2001). Public affairs and political strategy: theoretical foundations. Journal of Public Affairs, 1(4), 305-329.

Gormley, W. T. (1979). A test of the revolving door hypothesis at the FCC. American Journal of Political Science, 23(4), 665-683.

Greenwood, J. (2011). Interest representation in the European Union. Basingstoke, UK: Palgrave Macmillan.

Grossman, G. M., \& Helpman, E. (1996). Electoral competition and special interest politics. The Review of Economic Studies, 63(2), 265-286.

Harvey, W. S. (2011). Strategies for conducting elite interviews. Qualitative Research, 11(4), 431-441.

Hillman, A. J., \& Hitt, M. A. (1999). Corporate political strategy formulation: a model of approach, participation, and strategy decisions. Academy of management review, 24(4), 825-842.

Hillman, A. J., Keim, G. D., \& Schuler, D. (2004). Corporate political activity: a review and research agenda. Journal of Management, 30(6), 837-857.

Hillman, A. J., Withers, M. C., \& Collins, B. J. (2009). Resource dependence theory: a review. Journal of Management, 35(6), 1404-1427.

Hix, S., \& Marsh, M. (2007). Punishment or protest? Understanding European Parliament elections. Journal of Politics, 69(2), 495-510.

Hobolt, S. B., Spoon, J.-J., \& Tilley, J. (2009). A vote against Europe? Explaining defection at the 1999 and 2004 European Parliament elections. British Journal of Political Science, 39(1), 93-115.

Hochschild, J. L. (2009). Conducting intensive interviews and elite interviews, Workshop on Interdisciplinary Standards for Systematic Qualitative Research (Vol. February 2016). 
Keim, G. (2001). Managing business political activities in the USA: bridging between theory and practice. Journal of Public Affairs, 1(4), 362-375.

Keim, G., \& Baysinger, B. (1988). The efficacy of business political activity: competitive considerations in a principal-agent context. Journal of Management, 14(2), 163-180.

Kohler-Koch, B., \& Quittkat, C. (1999). Intermediation of interests in the European Union. Arbeitspapiere - Mannheimer Zentrum für Europäische Sozialforschung Mannheim, 9.

Kohler-Koch, B., Quittkat, C., \& Kurczewska, U. (2013). Interest intermediation in the European Union revisited: report on a survey study. Arbeitspapiere - Mannheimer Zentrum für Europäische Sozialforschung Mannheim, 151.

LaPira, T. M., \& Thomas, H. F. (2014). Revolving door lobbyists and interest representation. Interest Groups \& Advocacy, 3(1), 4-29.

Lawton, T., McGuire, S., \& Rajwani, T. (2013). Corporate political activity: a literature review and research agenda. International Journal of Management Reviews, 15(1), 86-105.

Lawton, T., \& Rajwani, T. (2011). Designing lobbying capabilities: managerial choices in unpredictable environments. European Business Review, 23(2), 167-189.

Lawton, T., Rajwani, T., \& Doh, J. (2013). The antecedents of political capabilities: A study of ownership, cross-border activity and organization at legacy airlines in a deregulatory context. International Business Review, 22(1), 228-242.

Lazarus, J., McKay, A., \& Herbel, L. (2016). Who walks through the revolving door? Examining the lobbying activity of former members of Congress. Interest Groups \& Advocacy, 5(1), 82-100.

Lazarus, J., \& McKay, A. M. (2012). Consequences of the revolving door: evaluating the lobbying success of former congressional members and staff, MPSA conference. Chicago, April 2012.

Lindblom, C. (1977). Politics and markets: the world's political economic systems. New York, NY: Basic Books.

Lord, M. D. (2000). Corporate political strategy and legislative decision making: the impact of corporate legislative influence activities. Business \& Society, 39(1), 76-93.

Lux, S., Crook, T. R., \& Woehr, D. J. (2011). Mixing business with politics: a meta-analysis of the antecedents and outcomes of corporate political activity. Journal of Management, 37(1), 223-247.

Mahoney, C. (2004). The power of institutions: state and interest group activity in the European Union. European Union Politics, 5(4), 441-466.

Mahoney, C. (2007). Lobbying success in the United States and the European Union. Journal of Public Policy, 27(01), 35-56.

Mahoney, C., \& Beckstrand, M. J. (2011). Following the money: European Union funding of civil society organizations. JCMS: Journal of Common Market Studies, 49(6), 1339-1361.

Majone, G. (1997). From the positive to the regulatory state: causes and consequences of changes in the mode of governance. Journal of Public Policy, 17(02), 139.

Mäkelä, K., Sumelius, J., Höglund, M., \& Ahlvik, C. (2012). Determinants of strategic HR capabilities in MNC subsidiaries. Journal of Management Studies, 49(8), 1459-1483.

Marcus, A. A., \& Kaufman, A. M. (1988). The continued expansion of the corporate public-affairs function. Business Horizons, 31(2), 58-62.

Martin, C. J. (1994). Business and the new economic activism: the growth of corporate lobbies in the sixties. Polity, 27(1), 49-76.

Martin, C. J. (1995). Nature or nurture? Sources of firm preference for national health reform. American Political Science Review, 89(04), 898-913.

Marx, T. G. (1986). Integrating public affairs and strategic planning. California Management Review, 29(1), 141-147.

Masters, M. F., \& Keim, G. D. (1985). Determinants of PAC participation among large corporations. The Journal of Politics, 47(4), 1158-1173. 
McWilliams, A., Van Fleet, D. D., \& Cory, K. D. (2002). Raising rivals' costs through political strategy: an extension of resource-based theory. Journal of Management Studies, 39(5), 707-724.

Meznar, M. B., \& Nigh, D. (1995). Buffer or bridge? Environmental and organizational determinants of public affairs activities in american firms. The Academy of Management Journal, 38(4), 975-996.

Miller, R. W., \& Johnson, J. D. (1970). Corporate ambassadors to Washington. Washington, DC: American University, Center for the Study of Private Enterprise.

Moravcsik, A. (2002). Reassessing legitimacy in the European Union. JCMS: Journal of Common Market Studies, 40(4), 603-624.

Oliver, C., \& Holzinger, I. (2008). The effectiveness of strategic political management: A dynamic capabilities framework. Academy of Management Review, 33(2), 496-520.

Post, J. E., Murray, E. A., Dickie, R. B., \& Mahon, J. F. (1983). Managing public affairs: the public affairs function. California Management Review, 26(1), 135.

Schuler, D. A., Rehbein, K., \& Cramer, R. D. (2002). Pursuing strategic advantage through political means: a multivariate approach. Academy of Management Journal, 45(4), 659-672.

Schumpeter. (2010, 24 June 2010). Too many chiefs. Inflation in job titles is approaching Weimar levels. The Economist, Retrieved November 2015 from http://www.economist.com/node/16423358

Shaffer, B. (1995). Firm-level responses to government regulation: theoretical and research approaches. Journal of Management, 21(3), 495-514.

Shaffer, B., \& Hillman, A. J. (2000). The development of business-government strategies by diversified firms. Strategic Management Journal, 21(2), 175.

Stigler, G. J. (1971). The theory of economic regulation. The Bell Journal of Economics and Management Science, 2(1), 3-21.

Taminiau, Y., \& Wilts, A. (2006). Corporate lobbying in Europe, managing knowledge and information strategies. Journal of Public Affairs, 6(2), 122-130.

Tansey, O. (2007). Process tracing and elite interviewing: a case for non-probability sampling. PS: Political Science \& Politics, 40(04), 765-772.

Teece, D., \& Pisano, G. (1994). The dynamic capabilities of firms: an introduction. Industrial and Corporate Change, 3(3), 537-556.

Teece, D. J. (2007). Explicating dynamic capabilities: the nature and microfoundations of (sustainable) enterprise performance. Strategic management journal, 28(13), 1319-1350.

Vannoni, M. (2015). Explaining the variation in the Europeanization of business: an institutionalist theory. Journal of European Public Policy, 22(10), 1-22.

Vogel, D. (1978). Why businessmen distrust their state: the political consciousness of American corporate executives. British Journal of Political Science, 8(1), 45-78.

Vogel, D. (1987). Political science and the study of corporate power: a dissent from the new conventional wisdom. British Journal of Political Science, 17(4), 385-408.

Vogel, D. (1996a). Kindred strangers: the uneasy relationship between politics and business in America. Princeton, NJ: Princeton University Press.

Vogel, D. J. (1996b). The study of business and politics. California Management Review, 38(3), 146.

Wang, H. C., \& Barney, J. B. (2006). Employee incentives to make firm-specific investments: Implications for resource-based theories of corporate diversification. Academy of Management Review, 31(2), 466-476.

Wilson, G. K. (1990). Corporate political strategies. British Journal of Political Science, 20(02), 281-288.

Wilts, A., \& Quittkat, C. (2004). Corporate interests and public affairs: organised business-government relations in EU member states. Journal of Public Affairs, 4(4), 384-399.

Wonka, A., Baumgartner, F. R., Mahoney, C., \& Berkhout, J. (2010). Measuring the size and scope of the EU interest group population. European Union Politics, 11(3), 463-476. 
Yoffie, D. (1984). Corporate strategies for political action: a rational model. In A. Marcus, A. KAufman \& D. Beam (Eds.), Business Strategy and Public Policy. New York, NY: Quorum Books.

Yoffie, D. B. (1985). Interest groups vs. individual action : an analysis of corporate political strategies. In J. Badaracco (Ed.) (Rev. ed.). Boston, MA: Division of Research, Harvard Business School.

Yoffie, D. B., \& Bergenstein, S. (1985). Creating political advantage: The rise of the corporate political entrepreneur. California Management Review, 28(1), 124.

Zollo, M., \& Winter, S. G. (2002). Deliberate learning and the evolution of dynamic capabilities. Organization Science, 13(3), 339-351. 
Table 1. Business-Government Relations and the Strategic Management of Government Affairs in the US and EU

\begin{tabular}{|c|c|c|}
\hline & US & EU \\
\hline $\begin{array}{l}\text { Business-government } \\
\text { Relations }\end{array}$ & & \\
\hline Logic & Economic transaction & Trust-based relationship \\
\hline Currency & Votes and funds & Technical information \\
\hline Time Horizon & Short-term & Long-term \\
\hline $\begin{array}{l}\text { Strategic Management of } \\
\text { Government Affairs }\end{array}$ & & \\
\hline Delegation & External & In-house \\
\hline Appointment & High turnover & High longevity \\
\hline Skillset & $\begin{array}{l}\text { Personal contacts and } \\
\text { knowledge of the political } \\
\text { machine }\end{array}$ & Knowledge of the industry \\
\hline Work experience & $\begin{array}{l}\text { Work experience in the public } \\
\text { sector }\end{array}$ & $\begin{array}{l}\text { Work experience in the } \\
\text { private sector }\end{array}$ \\
\hline $\begin{array}{l}\text { Education } \\
\text { background }\end{array}$ & Law and public relations & Social sciences \\
\hline
\end{tabular}



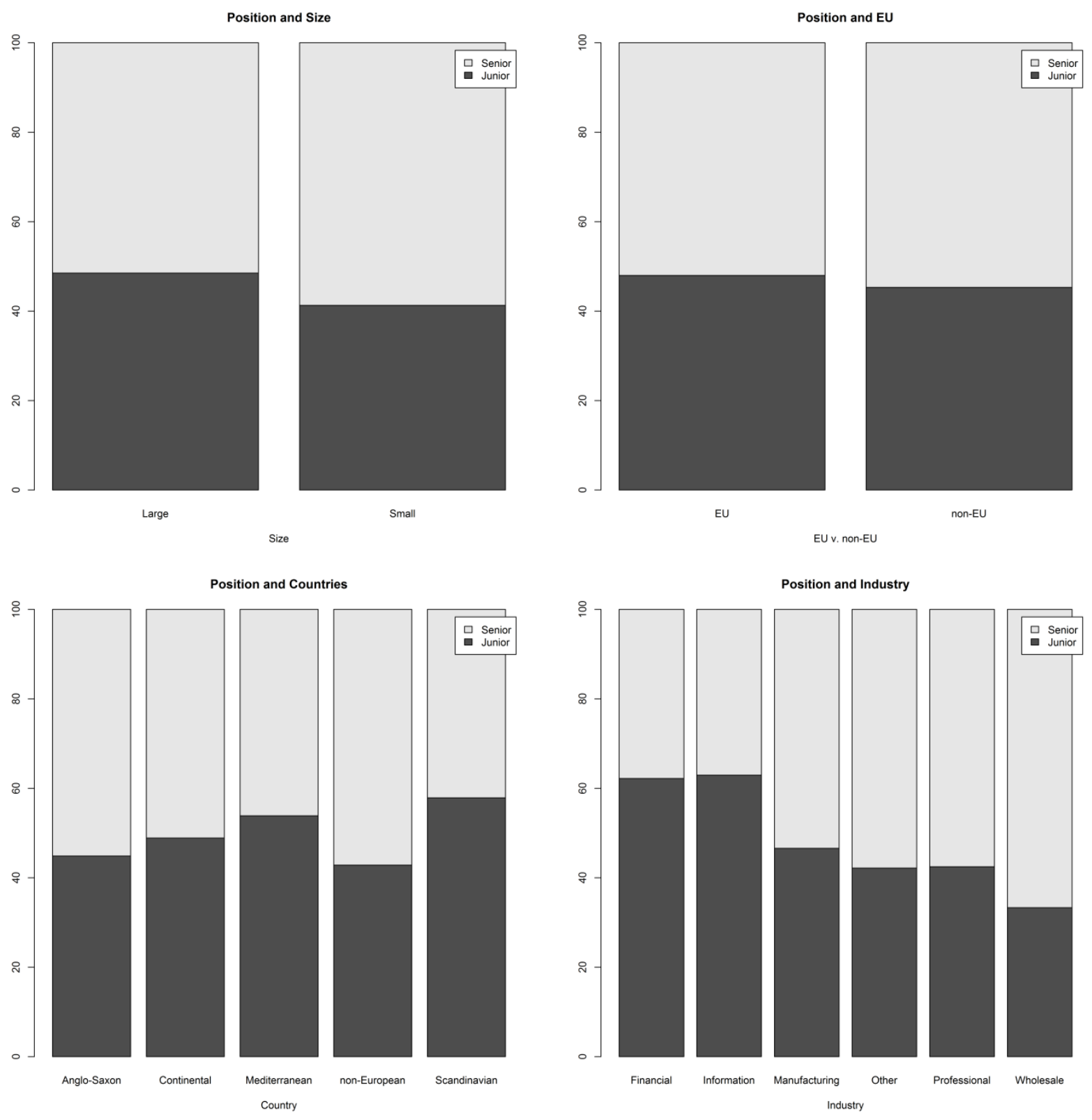

Figure 1. Differentiation of Government Affairs: Senior and Junior Positions of Government Affairs across Firm Size, Country and Industry 

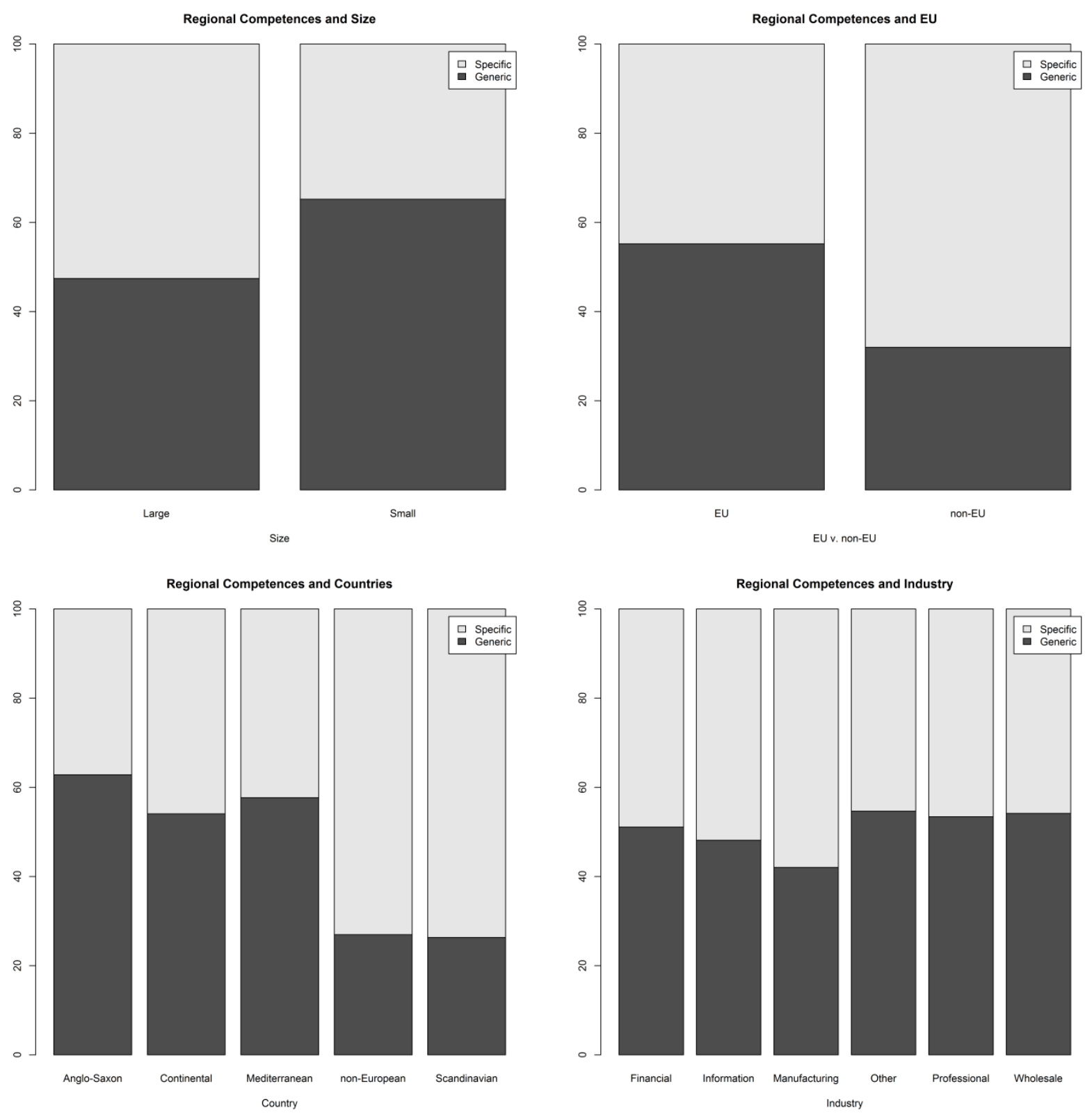

Figure 2. Decentralization of Government Affairs: Geographical Representation of Government Affairs across Firm Size, Country and Industry 

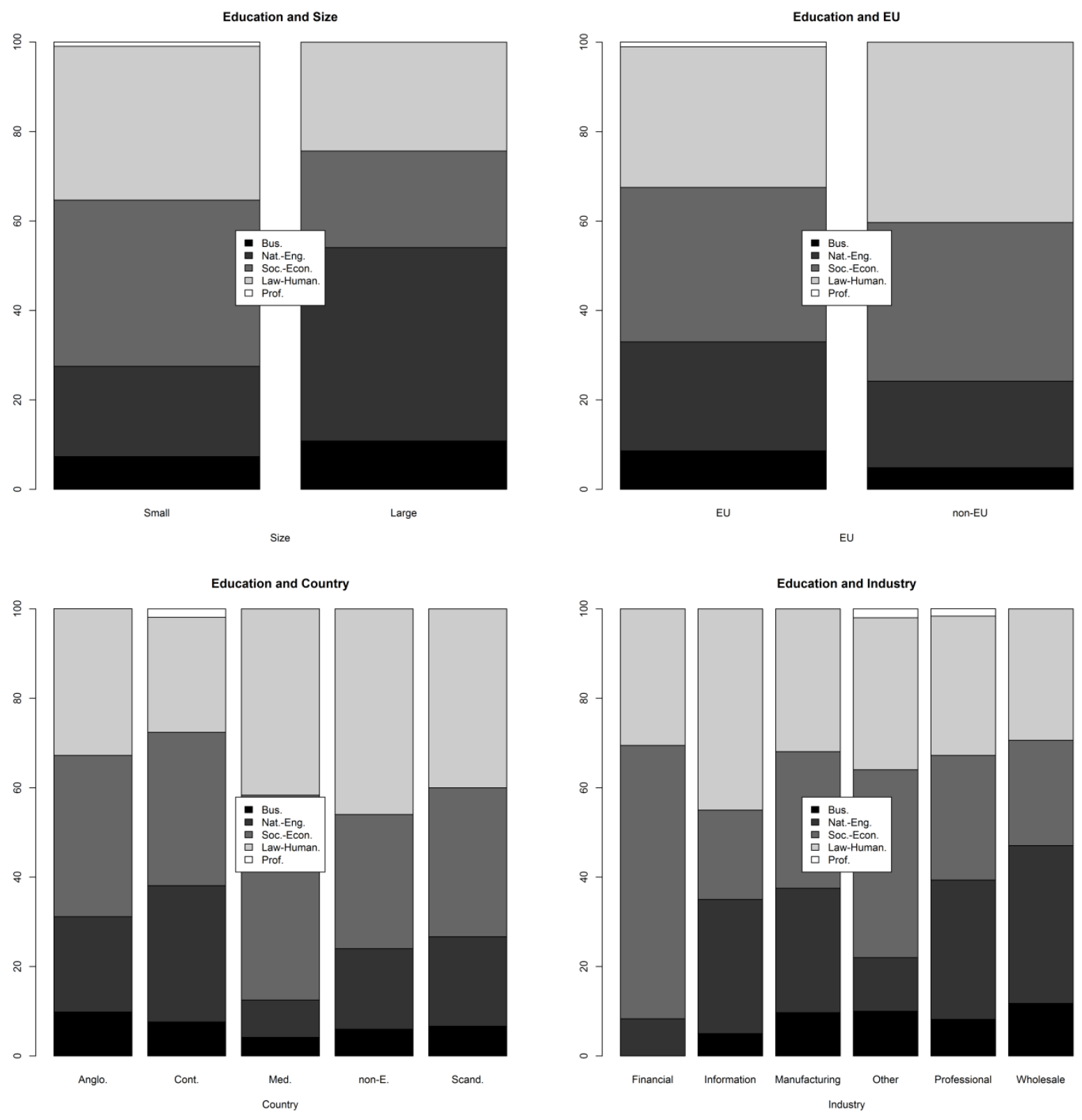

Figure 3. Government Affairs Managers' Education Background across Firm Size, Country and Industry 


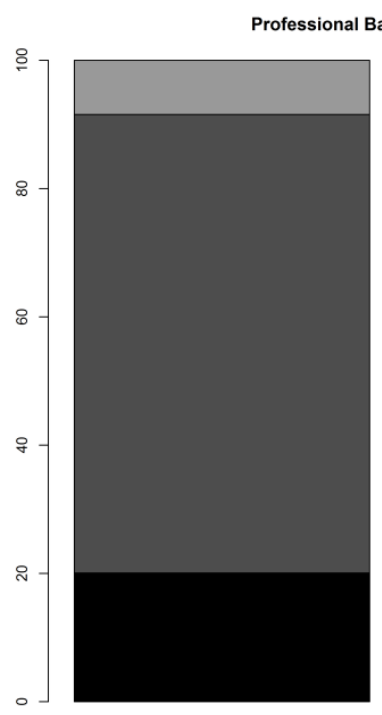

Small

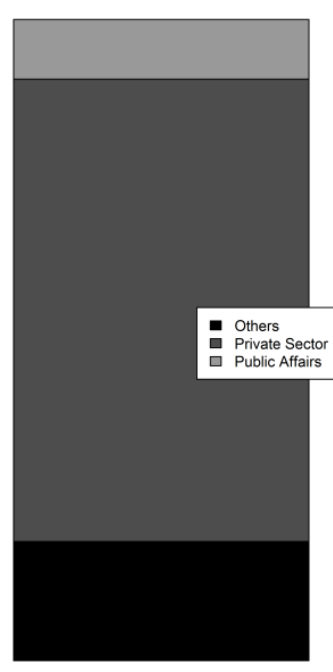

Large

Size

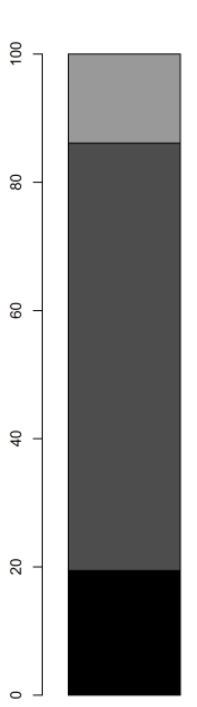

Anglo.
Professional Background and Country

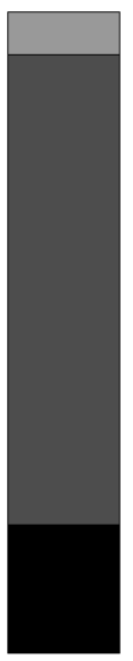

Cont.

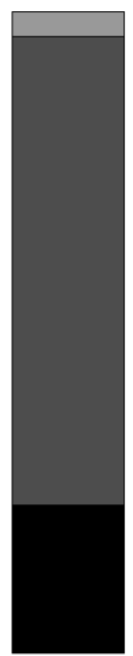

Med.

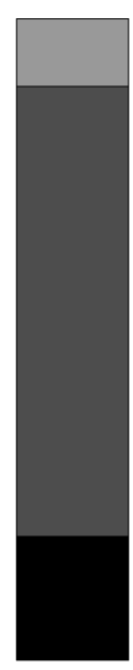

non-E. Scand.

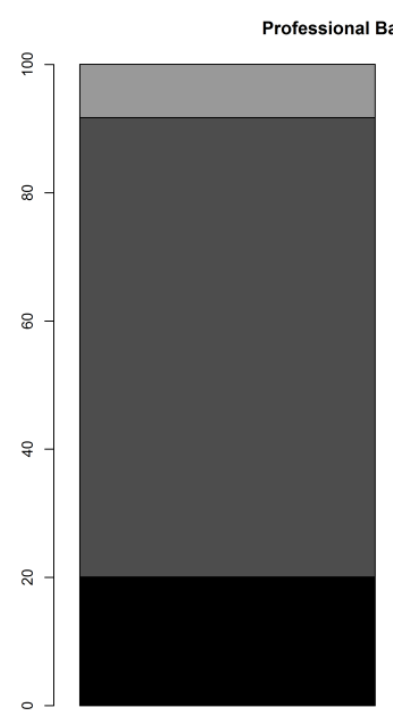

EU

Professional Background and Industry

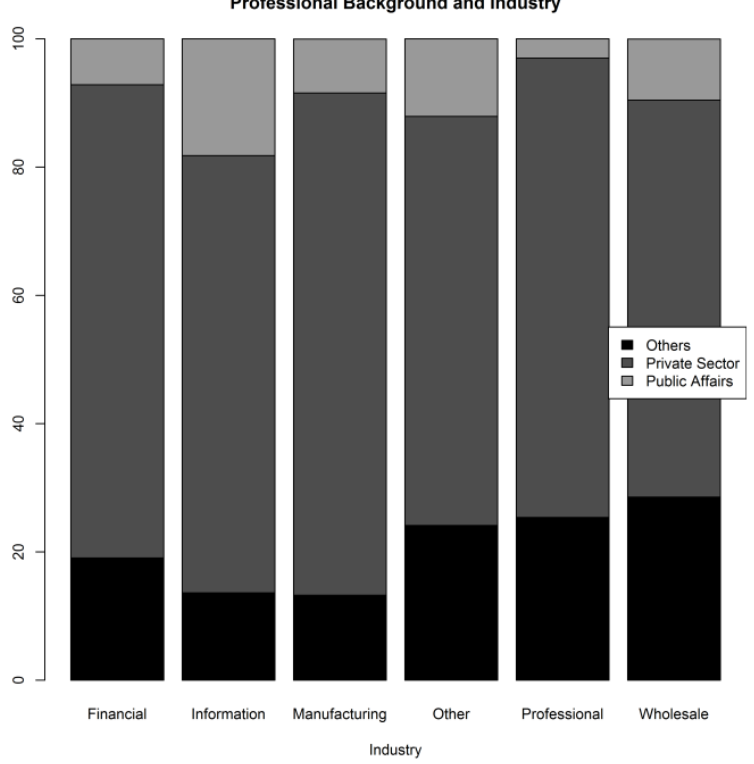

Figure 4. Government Affairs Managers' Professional Background across Firm Size, Country and Industry 
Table 2. Multivariate Regression Analysis: Decentralization of Government Affairs and Lobbying Spending

Decentralization

(1)

$0.942^{* * *}$

$(0.324)$

Firm Size - Small

Country - Continental

Country - Mediterranean

Country - non European

Country - Scandinavian

Industry - Information

Industry - Manufacturing
(2)

$1.014^{* * *}$

(0.352)

$-0.265$

$-0.002$

(0.492)

(0.518)

0.204

(0.386)

0.431

(0.574)

$1.644^{* * *}$

(0.512)

$1.459^{* *}$

(0.663)

0.075

(0.698)

$-0.034$

(0.473)

0.057

Industry - Other 
(0.507)

Industry - Professional

$-0.195$

(0.477)

Industry - Wholesale

$-0.241$

(0.631)

Constant

0.075

0.085

$-0.426$

(0.158)

(0.164)

$(0.502)$

Observations

224

222

218

Log Likelihood

$-147.838$

$-146.723$

$-135.179$

Note:

${ }^{*} \mathrm{p}<0.1^{* *} \mathrm{p}<0.05^{* * *} \mathrm{p}<0.01$


Table 3. Multivariate Regression Analysis: Decentralization of Government Affairs and Government Office Size

\section{Decentralization}

(1)

$\begin{array}{lll}0.154^{* * *} & 0.156^{* * *} & 0.162^{* * *} \\ (0.059) & (0.059) & (0.061)\end{array}$

Firm Size - Small

$-0.274$

0.015

$(0.468)$

(0.498)

Country - Continental

0.269

(0.369)

Country - Mediterranean

0.179

(0.559)

Country - non European

$1.594^{* * *}$

(0.491)

Country - Scandinavian

$1.398^{* *}$

(0.648)

Industry - Information

0.178

(0.667)

Industry - Manufacturing

0.030

$(0.461)$

$-0.045$

Industry - Other 
(0.490)

Industry - Professional

$-0.178$

(0.460)

Industry - Wholesale

$-0.573$

(0.603)

Constant

$-0.108$

$-0.103$

$-0.577$

(0.206)

(0.209)

(0.493)

Observations

242

240

236

Log Likelihood

$-160.119$

$-158.838$

$-146.731$

Note:

${ }^{*} \mathrm{p}<0.1^{* *} \mathrm{p}<0.05^{* * *} \mathrm{p}<0.01$


${ }^{\mathrm{i}}$ Information on the dataset is provided below.

ii I001, Brussels, 3 February 2016.

iii I009, London, 22 June 2016.

iv I007, Brussels, 3 March 2016.

v I007, Brussels, 3 March 2016.

vi I007, Brussels, 3 March 2016.

vii I006, Brussels, 16 February 2016.

viii I001, Brussels, 3 February 2016.

ix I009, London, 22 June 2016.

${ }^{x}$ I002, Brussels, 3 February 2016.

xi I009, London, 22 June 2016.

xii I008, Brussels, 3 March 2016.

xiii I001, Brussels, 3 February 2016.

xiv I002, Brussels, 15 February 2016. 